\title{
DA'WAH AMIDST RELIGIOUS AND CULTURAL DIFFERENCES (STUDY OF Q.S. AL-HUJURAT:13)
}

\author{
Bela Ardila \\ Universitas Islam Negeri Sunan Kalijaga Yogyakarta \\ belaardila99@gmail.com
}

\begin{abstract}
The Unitary State of the Republic of Indonesia is a country that has many cultures, this is evidenced by the Indonesian slogan "Bhinneka Tunggal Ika" which means "different but still one thing". In a variety of cultures, humans need interaction with other humans, namely what is known as the word "communication". Peace in the midst of cultural differences is the application of Allah's orders in the teachings of Islam. Created from a man and woman and made humans into nations and tribes so that humans know each other to be devoted to Allah SWT. Contextual interpretation of the Quran and considering the socio-historical context in interpreting a text is so urgent and important. This is directly related to the spirit of the Koran, where Muslims must always learn and develop a number of knowledge by involving the text of the Qur'an on the one hand and dialogue with reality on the other. Da'wah bil-hal and verbally become a milestone of success for community harmony in Cempaka Putih Village, Jelutung District, Jambi City, Jambi Province.
\end{abstract}

\section{Keywords: Intercultural Communication, Contextual of the Quran, Da'wah}

\section{INTRODUCTION}

According to Everett M. Rogers, communication is a process in which an idea is transferred from a source to one or more recipients, with the intention of changing their behavior. Communication can not be seen as an activity that connects humans in a passive state, but communication must be seen as a process that connects humans through a set of actions that are continuously updated. This can be proven by the existence of one of the studies in communication science, namely intercultural communication. Communication and culture are not just two words but two concepts that cannot be separated, it must be noted that the study of intercultural communication can be interpreted as a study that emphasizes the effect of culture on communication. ${ }^{1}$

Deddy Mulyana and Jalaluddin Rakhmat have mentioned that the main problem in intercultural communication is errors in social perception caused by cultural differences that affect the perception process. Their approach is also based

${ }_{1}^{1}$ Alo Liliweri, Dasar-dasar Komunikasi Antarbudaya (Yogyakarta: Pustaka Pelajar, 2013), p. 8 
on a fundamental assumption: parties to intercultural communication must have an honest and sincere desire to communicate and expect mutual understanding. This assumption requires positive attitudes from intercultural communicators and the elimination of superior-inferior relationships based on membership in certain cultures, races, or ethnic groups. ${ }^{2}$ The simplest definition of intercultural communication can also be given, namely interpersonal communication carried out by people from different cultural backgrounds.

In many ways, the relationship between culture and communication is reciprocal. Both influence each other. What we talk about, how we talk about it, what we see, pay attention to, or ignore, how we think, and what we think are influenced by culture. In turn, what we talk about, how we talk about it, and what we see help shape, define, and liven up our culture. Culture cannot exist without communication, and communication cannot exist without culture. Neither can change without causing the other to change.

In Indonesia, conflicts often occur which cause problems due to the depletion of tolerance between religions and cultures, various conflict cases such as: in Aceh, Timika (Papua), Ambon (Maluku), Pontianak (West Kalimantan), SampitMataram (NTB) , and Poso (Central Sulawesi). ${ }^{3}$ Another fact that must be considered is the success of every ethnic group between adherents of a culture to coexist with an attitude of tolerance in existing cultural differences.

Islamic da'wah is nothing but an activity of communicating the teachings of Allah contained in the Al-Quran and as-Sunnah, so that humans take it to be their way of life. As for the implementation, it must be done through the characteristics of communication by always being in touch with Allah and brotherhood.

The basic foundation of da'wah is faith and pious deeds based on science, while the basis for its implementation is vision, logic, and truth, in addition to describing the process of da'wah related to philosophy and education, as well as reminding that the Koran requires using reason.

2 Deddy Mulyana and Jalaluddin Rakhmat, Komunikasi Antarbudaya Panduan Berkomunikasi Dengan Orang-orang Berbeda Budaya (Bandung: PT Remaja Rosdakarya, 2010), p. 34-35.

3 Johni Najwan, Konflik Antarbudaya dan Antar Etnis di Indonesia serta Alternatif Penyelesaiannya (Jambi: Jurnal Hukum Edisi Khusus, 2009), p. 197. 
Cempaka Putih Village is a village that shows that its people respect and respect each other, need each other, and are harmonious.

In Islam, looking down on other people just because of differences in skin color, ethnicity, and religion is something that is strictly prohibited. This is stated in the Qur'an Surah Al-Hujurat verse 13, which means "O people! Indeed, We created you from a male and a female, then We made you into nations and tribes so that you might know one another. Verily, the most honorable of you in the sight of Allah is the one who is most pious. Verily, Allah is All-Knowing, All-Knowing."

In this sura explains about Allah created man from a man (Adam) and a woman (Eve) and made people into nations and tribes so that they know each other and help each other. Allah's assertiveness in this surah is to abolish "caste" in Arab society; reaffirming that as a servant of Allah, it is not lineage, wealth, form or status of work that determines the virtue of a servant of Allah, but piety. And that piety cannot be bought or achieved by relying on the virtues of lineage, tribe or clan, but by good deeds. Unfortunately, lately, many people want to restore the "caste" of Arab society that has been removed by the Prophet.

Imam Muslim and Ibn Majah narrated from Abu Hurairah that the Messenger of Allah said: "Allah does not look at your appearance and wealth, but Allah looks at your hearts and deeds."

Seeing from the discussion, the author is interested in studying the contextual interpretation of the Qur'an in Q.S. Al-Hujurat:13 with a blend of Intercultural Communication disciplines applied by the people of Cempaka Putih Village, Jelutung District, Jambi City.

\section{DISCUSSION}

Phillipsen describes culture as a social construction and a historically transmitted pattern of symbols, meanings, opinions, and rules. Basically, culture is a code. There are four crucial dimensions that can be used to compare cultures, namely power distance, masculinity, uncertainty avoidance, and individualism. ${ }^{4}$

${ }^{4}$ Heri Rahmatsyah Putra, "Teori Komunikasi Antarbudaya", accessed through http://herikomi.logspot.co.id/2016/08/teoi-komunikasi-antarbudaya.html, 17 November 2020. 
The theories contained in intercultural communication by Griffin are, Anxiety/Uncertainty Management Theory, Face Negotiation Theory, and Speech Codes Theory.

The first theory, published by William Gudykunst, focuses on cultural differences between groups and strangers. He intends that his theory can be applied to any situation where there is a difference between doubt and fear. The difference can be explained by whether a person is a member of a culture in a different context. high context or low context cultures. High context cultures rely heavily on the whole situation to interpret events and low context cultures rely more on the clear verbal content of messages. William Gudykunst used the term effective communication to refer to processes of minimizing misunderstanding and he also believed that anxiety and uncertainty were the basic causes of communication failure in intergroup situations.

The second theory, published by Stella Ting-Toomey, helps explain cultural differences in responding to conflict. Ting-Toomey assumed that people in every culture would always be negotiating faces. The term is a metaphor for our public self-image, the way we want others to see and treat us. Face work refers to verbal and non-verbal messages that help maintain and store face loss, and maintain a respectable face. Our identities can always be questioned, and conflict-driven anxiety and uncertainty make us helpless. The postulate of this theory is that the face work of people from individual cultures will be different from collectivist cultures. While face work is different, conflict handling styles also vary.

And in the third theory, published by Gerry Philipsen, it tries to answer about the existence of speech code in a culture, how its substance and strength are in a culture. He conveys the following propositions: wherever there is a culture, there is found a distinctive speech code. Significant speech relies on the speech code of the speaker and listener to create and interpret their communication. Terms, rules, and premises are linked to the speech itself. The use of a shared speech code is to create sufficient conditions to predict, explain, and control discourse formulas about intelligence, prudence (wise, cautious) and morality of communication behavior. Furthermore, there are several terminological definitions used and need to be explained in this study, namely: 


\section{Concept of Culture}

Humans and culture are never separated, together make up life. Humans gather themselves as a socio-cultural unit, becoming a society. Humans give birth, produce, grow, and develop culture. There is no human without culture, on the other hand there is no culture without humans, there is no citizen without culture, there is no culture without citizens.

Today culture is defined as a manifestation of the life of each person and every group. Culture is not defined as a noun, now it is more interpreted as a verb associated with human activities. Culture is the basic assumptions and beliefs among members of a group or organization. In the Big Indonesian Dictionary "Culture" means: mind, reason, mind, or habit (something that has become a habit that is difficult to change). ${ }^{5}$

Formally culture is defined as the order, knowledge, experience, belief, value, attitude, meaning, hierarchy, religion, time, role, relationship, space, concept of the universe, material objects and property that a large group of people acquire from generation to generation through effort. individual and group.

Culture describes the way we do things. Hasstrup asserts, culture consists of relationships, not just a stable system. Schwart and Davis define culture as a set of beliefs and expectations shared by all members of the organization. Intercultural communication emphasizes the main aspect, namely interpersonal communication between communicators and communicants of different cultures. ${ }^{6}$

\section{The Nature of Intercultural Communication}

Deddy Mulyana defines intercultural communication as communication that occurs between people of different religions, nations, races, languages, education

5 Departemen Pendidikan dan Kebudayaan, Kamus Besar Bahasa Indonesia, (Jakarta:Balai Pustaka, 2005), p.169

${ }^{6}$ Alo Liliweri, Gatra-gatra Komunikasi Antar Budaya (Yogyakarta: Pustaka Pelajar, 2001), p. 13. 
levels, social status, and even gender. ${ }^{7}$ The definition of intercultural communication according to Alo Liliweri is a process of analyzing or comparing one cultural phenomenon with another cultural phenomenon. According to Fiber Luce as quoted by Liliweri said that essentially cross-cultural studies are a comparative study that aims to compare, 1) certain cultural variables, 2) the consequences or consequences of cultural influences from two or more different cultural contexts. ${ }^{8}$

To improve intercultural communication, communicators must know their own culture, recognize personal behavior and communication style, selfmonitor, empathize, be aware of cultural differences in listening, feedback, develop communication flexibility, and learn about cultural adaptation. ${ }^{9}$

\section{Communication Mechanism/Process}

The communication process is how the sender of the message (the communicator) conveys the message to the recipient of the message (the communicant) by using certain media, so as to get an equation of meaning to create effective communication. The stages of the communication process start from Interpreting, Encoding, Sending, Traveling, Receiving, Re-encrypting, and ending with re-interpreting. The communication process is divided into two stages, namely primary and secondary.

a. a. Primary communication process: Primary communication process is the process of conveying one's thoughts and or feelings to others by using symbols (symbols) as media. Symbols as primary media in the communication process are language, gestures, signs, images, colors, and so on that are directly able to "translate" the thoughts and or feelings of the communicator to the communicant. In this process, language is the most widely used symbol. However, not everyone is good at words in using

7 Deddy Mulyana dan Jalaluddin Rakhmat, Komunikasi Antarbudaya Panduan Berkomunikasi Dengan Orang-orang Berbeda Budaya (Bandung: PT Remaja Rosdakarya, 2010), p. v.

${ }^{8}$ Alo Liliweri, Dasar-dasar Komunikasi Antarbudaya (Yogyakarta: Pustaka Pelajar, 2013), p. 365.

${ }^{9}$ Larry A. Samovar et. Al., Komunikasi Lintas Budaya Communication Between Cultures (Jakarta: Salemba Humanika, 2010, p. 491. 
language. Therefore, in the use of language, words contain two types, namely denotative (true meaning) and connotative (figurative meaning)..

b. Secondary communication process: The secondary communication process is the process of delivering messages by one person to another by using a tool or means as the second medium after using the symbol as the first medium.A communicator uses a second medium in launching his communication because the communicant as the target is located in a relatively distant place or in large numbers. Letters, telephone, telex, newspapers, magazines, radio, television, films, and many more are secondary media that are often used in communication. ${ }^{10}$

\section{Contextual Al-Quran}

In Islamic teachings, there are two sources that underlie these teachings, namely the Qur'an and the Sunnah of the Prophet. The Qur'an is a book that was revealed by God to the Prophet Muhammad. The Qur'an is the word of God and the presence of God in historical space and time. The Qur'an was revealed directly by Allah to the Prophet Muhammad through the Angel Gabriel, gradually over 22 years, 2 months and 22 days or an average of 23 years, starting from the 17th of Ramadan, when Prophet Muhammad was 40 years old until his death. in the year 632.11

The interpretation of the Qur'an is basically done to open the contents of the values contained in it. All forms of explanation of the Qur'an are efforts to uncover the veil of meaning to obtain the messages and instructions contained in it. In 'ulūm al-Qur'an wa Tafsr many ways are introduced to understand and interpret the Qur'an with the aim of revealing the messages of the Qur'an. In the history of the interpretation of the Qur'an, Hadith has an important role as a source of interpretation. It has also been previously stated in the Qur'an that the Prophet Muhammad was to explain the Qur'an. Contextual interpretation was

10 Ibid., 16.

11 Wikipedia, “Al- Qur'an”, accessed through: https://id.m.wikipedia.org/wiki/AlQuran, tanggal 6 November 2020. 
first put forward by the Prophet Muhammad when he was fostering the early Muslim community. ${ }^{12}$

The development of human life has progressed further than when the Qur'an was first revealed. The majority of Muslims think that only the Qur'an is the guide of life, in fact besides the Qur'an, Hadith is also a guide to life. The Qur'an was revealed far from the present, but the interpretations of the Qur'an continue to this day and need to be reviewed and developed so that its function as a problem solver for the development of human life continues as it applies during the revelation process.

The interpretation of the Qur'an from the beginning of Islam until now has varied according to the intellectual capacity and inclination of the interpreter. The diversity of interpretations not only proves the flexibility and elasticity of the content of the Qur'an on the development of human life, but also proves the existence of legitimate legitimacy to interpret the Qur'an in accordance with the wishes of each.

One of the diversity of interpretations is contextual interpretation. This interpretation is a lot and is often discussed by people. It is an attempt not to cult the works of interpretation that already exist. Because with this interpretation, the works of interpretation that have existed previously are only as references or references which if their content is still in accordance with the demands of the times, it will be taken and developed, but if not, then the works are just like piles of paper bundles that only exist. can decorate library collections as a wealth of Islamic scientific treasures.

\section{ASBABUN NUZUL SURAH AL- HUJURAT: 13}

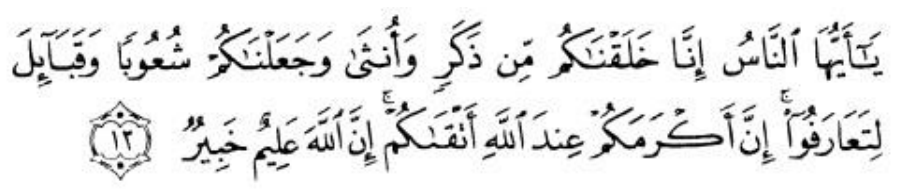

12 Muhammad Hasbiyallah, "Paradigma Tafsir Kontekstual: Upaya Membumikan NilaiNilai Al-Qur'an", Al-Dzikra Jurnal Studi Ilmu al-Qur'an dan al-Hadits, Volume 12, No. 1, Juni Tahun 2018, p. 22. 
Meaning: "13. O mankind, verily We created you from a male and a female and made you into nations and tribes so that you may know one another. Verily, the most honorable of you in the sight of Allah is the one who is most pious among you. Verily, Allah is All-Knowing, All-Knowing." (al-Hujuraat: 13).13

Ibn Abi Hatim narrated from Abi Beginkah who said, "After the liberation of the city of Mecca, Bilal went up to the Kaaba and gave the call to prayer. Seeing this, some people then said, "How is it possible that this black slave who actually sounded the call to prayer above Ka' bah!' others said (in a mocking tone), 'Would Allah be angry if he didn't call the call to prayer?' Allah then sent down this verse."

Ibn 'Asakir narrates in the book Al-Mubhamaat, "I found a handwriting from Ibn Basykual which states that Abu Bakr bin Abi Dawud narrated in his commentary, 'This verse was revealed regarding Abi Hindun. Once, the Messenger of Allah ordered the Bani Bayadhah to marry Abu These Hindus were with women from their tribe. However, they said, 'O Messenger of Allah, how can we marry our daughter to a slave.' In response, this verse came down.'14

Allah's assertiveness in this surah is to abolish "caste" in Arab society; reaffirming that as a servant of Allah, it is not lineage, wealth, form or status of work that determines the virtue of a servant of Allah, but piety. And that piety cannot be bought or achieved by relying on the virtues of lineage, tribe or clan, but by good deeds. Unfortunately, lately, many people want to restore the "caste" of Arab society that has been removed by the Prophet.

Imam Muslim and Ibn Majah narrated from Abu Hurairah that the Messenger of Allah said: "Allah does not look at your appearance and wealth, but Allah looks at your hearts and deeds."

\section{Elements of Communication in Islamic Da'wah}

Our world has entered the age of technology and data, where both citizens and mankind are in the process of becoming citizens of communication. This means that all aspects of life will depend on the data obtained and received by

\footnotetext{
13 Tim Penterjemah dan Penafsir Al-Qur'an dan Terjemahannya (Semarang:Departemen Agama RI, 1998)

14 Imam as-Suyuthi, Asbabun Nuzul: Sebab-sebab Turunnya Ayat al-Qur'an, Jakarta: Qisthi Press, 2017, p. 414.
} 
residents. The very basic impact on religious life is definitely the shift in patterns and religious orientations of Muslims. For that it is necessary and a necessity, if the da'wah must reformat and construct itself to be more efficient and operational. This effort is very meaningful between the pattern of da'wah activities that still glorify the old treasures and the strengthening of religious fundamentalism. The use of communication science in the development of da'wah at the crucial point is like a foothold. As for the consideration of establishing the foundation of communication science in the development of da'wah science, it is because communication science already has an established and easy-to-understand system in its scientific development. 15

The term communication comes from the Latin "communicatio", comes from "communs" which means "same". Same here, namely "same meaning". Communication must have at least a "common sense" between the two participating parties. In simple terms, communication can be defined as the process of delivering messages by communicators to communicants through the media that gives rise to certain consequences. Etymologically the word da'wah comes from Arabic which means: an appeal, an invitation, a call. Da'wah communication is communication whose elements are adjusted to the vision and mission of da'wah ${ }^{16}$. According to Toto Tasmara, that da'wah communication is a distinctive form of communication in which a communicator delivers messages that are sourced or in accordance with the teachings of the Qur'an and Sunnah, with the aim that other people can do good deeds in accordance with the messages conveyed. inform. So in terms of the process of da'wah communication, it is almost the same as communication in general, but the difference is only in the method and goals to be achieved.

\section{MACAM-MACAM METODE DAKWAH}

15 Wahyu Oktaviana, Skripsi "Dakwah bil-hal sebagai metode dakwah pada masyarakat srikaton seputih Surabaya Kabupaten Lampung Tengah”, 2020, p. 30.

${ }^{16}$ Marwantika, Asna. 2019. "Potret Dan Segmentasi Mad'u Dalam Perkembangan Media Di Indonesia”. Al-Adabiya: Jurnal Kebudayaan Dan Keagamaan 14 (01), 1-14. https://doi.org/10.37680/adabiya.v14i01.100. 
The general basis for the da'wah method is the Qur'an Surah An-Nahl verse 125, where in that verse there is an accurate da'wah method, which is divided into three, Bi Al-Hikmah, Dakwah Bil Hal, and Da'wah Bil oral.

Da'wah, in terms of language, means a call, an appeal or an invitation. Da'wah has the meaning of inviting to virtue, humans who invite to virtue and also those who are invited to virtue. Regarding this, in fact there is a process, which has several methods. The method is da'wah bill oral. Da'wah bil oral is defined as the delivery of data on da'wah messages through oral. Da'wah bil oral is an invitation or dissemination of religious values with a verbal communication approach through spoken (verbal) and written language, such as lectures, speeches, writings and essays. Da'wah bil oral is da'wah carried out orally, which is tried, among others, by lectures, sermons, discussions, advice and others. Da'wah bil oral can also be interpreted as a procedure for expressing and delivering da'wah that is more oriented to lecturing, speeches, face-to-face and so on. Based on this definition, da'wah bil oral is a da'wah method carried out by the da'i using his mouth during da'wah activities through speech which is carried out through lectures, speeches, khitobah, and others.

The obligation to carry out da'wah bill oral, in the Qur'an is contained in the QS. An-Nahl verse 125. The principle of da'wah can be found in the Qur'an and hadith with various guidelines so that communication runs well and effectively. The success of da'i bil oral also relies on the ability of the preacher to process and choose the right words, it is important for the preacher to know the use of the right words so as not to offend and according to the target, which has been explained in the Qur'an especially in detail. this is communication in da'wah bil oral activities.

\section{Da'wah in Cempaka Putih Sub-district}

Slamet Mulyana in his book says that Malay is in Jambi and Sriwijaya, in Palembang, both of which are maritime countries. Furthermore, in the book Pejuang Ulama and Ulama Pejuang Negeri Melayu Jambi by Hasan Basri Agus, the word Malay may have come from the name of a tributary called Sungai Melayu upstream of the Batang Hari 
River, Sumatra. ${ }^{17}$ There lies the Malay Kingdom about 1500 years ago before or during the Srivijaya Kingdom. From an etymological point of view, Malay words are said to be derived from Sanskrit; 'Melaya' which means 'hill' or 'high land'. There are also historical sources that say that the word 'Malay' comes from the Malay River in Jambi. Khirul A. Mastor, Putai Jin, and Martin Cooper said that 'Malays' (Malays) are those who are indigenous (Indegenous) in the Malaya region, an area in the Malay Peninsula. Malays also live in Brunei, Singapore and Indonesia, Southern Thailand and Cambodia as well as outside Southeast Asia. The explanation of one opinion is that the word Malay comes from the Tamil language which means mountains, maybe in the past Indian sailors and travelers came from the west coast of Sumatra through the Indian Ocean and saw the island full of mountains from one end to the other. The island is clearly Sumatra and the series of mountains is Bukit Barisan, therefore it is then called with Malay which means mountain or mountains. It is on this mountainous island that there live the tribes mentioned in the Malay History as follows; "Malay people, from Bukit Siguntang Mahamiru. ${ }^{18}$

When Islam Nusantara was centered in Pasai in the XIII century AD, Arab Muslim traders, Chinese Muslims and Nusantara Ulema tried to spread Islamic teachings to all corners of the archipelago by taking the Malacca Strait shipping route. Controlling trade routes in the Malacca Peninsula area which is marked by the Arab community controlling international trade in the Malacca Strait. Through these trade routes, the spread of Islam is increasingly experiencing very rapid development, especially in the Malay land area and even Islamic kingdoms have sprung up in the Malay land. This condition is very influential in encouraging the spread of Islamic teachings in the Jambi Malay State. The figure who introduced Islam to the Jambi Malay empire was an Arab named Ahmad Salim who is better known as Datuk Paduko Berhalo." The position of the Malacca Strait as a major shipping lane and the bustling Arab traders, has provided opportunities for Arab Muslim traders at least concentrate the group in a certain area.

17 Hasan Basri Agus, Pejuang Ulama dan Ulama Pejuang Negeri Melayu Jambi, (Jambi: Pusat Kajian Pengembangan Sejarah dan Budaya Jambi, 2012), hal. 11-18

18 Beni Agusti Putra. (2016). Islam Dalam Sejarah dan Kebudayaan Melayu. Jurnal humanika Vol. 1, No. 2, p. 197-198. 
However, the arrival of Arab Muslim traders from Persia, Cujarat and Chinese Muslims had actually been in the Malay country of Jambi through the port of Zabak in the XVM century. The port of Zabaq or Muaro Jambi has been visited by many Arab Muslim traders and Chinese Muslims as well as Nusantara Ulama since the XV century AD. Although Jambi is still devoid of Islamic historical artifacts, the metal kepeng found at the Muarojambi Temple site is similar to the IX century kepeng in The Lapo Tuo Barus site has strengthened the presence of Muslim traders in Jambi. The presence of Ahmad Salim or Ahmad Barus II or Ahmad llyas further strengthens it as a sign that Islam has spread to Arabs and Turks in the Malay country of Jambi. At that time the government of the Malay kingdom was held by Princess Selaras Pinang Masak as King of Jambi who ruled from 1460-1480 AD.

The story of the spread of Islam in the Malay community of Jambi begins with the story of Ahmad Salim or Ahmad Barus II or Ahmad Ilyas and his brother on their way to the island of Java. In the middle of the voyage, the ship they were traveling on was hit by a storm in the waters of the Malacca strait, the two brothers were separated. Ahmad Salim/Ahmad Barus II was stranded on an island in Ujung Jabung and was rescued by a passing fisherman and later became a guest of the King of Jambi Princess Selaras Pinang Masak. Meanwhile, the fate of his younger brother was stranded on the island of Java and then saved by a Majapahit queen.

Another story tells of the arrival of Ahmad Salim or Ahmad Barus II or Ahmad Ilyas, son of the Crown of the Sultanate of Turkey from Nasab Alawiyyin descended from Saidina Zainal Abidin bin Saidina Husein bint Fatimah Zahra bint Sayyidina Rasulullah SAW in the Jambi Malay Kingdom stems from the fatwa of a scholar advisor to the Sultan of Turkey to Sultan to find a country called Pasai because, the country will give birth to many guardians / auliya. Then the Sultan of Turkey prepared three units of sailing ships. Each sailing ship carrying a group of Turky Ulama sailed towards the Pasai Ocean. On the way, which is estimated to be in the area before the Malacca Strait, the three sailing ships separated. One sailing ship arrived at Pasai Aceh and there were other ships that arrived in Demak as well as ships carrying Ahmad Salim or Ahmad Barus II or Ahmad Ilyaster stranded at the end of the east coast of Sumatra or Ujung Labung where the Jambi Malay Kingdom was in 1120 H (XV M.) Ahmad Salim or Ahmad Barus met the King of Jambi, Puteri Selaras Pinang Masak, which ended in marriage and was given the title Datuk 
Paduko Berhalo. The presence of Ahmad Salim or Ahmad Barus If or Ahmad Ilyas in the Jambi Malay Kingdom at that time became patronage for the local ruler Puteri Selaras Pinang Masak in spreading Islam which began with the act of exterminating or destroying several idol statues found in Tanah Putus Ujung Jabung or known as Berhala Island as a place of worship for followers of the Hindu religion, the island was built by Tun Talanai when he was in power during the Old Malay Kingdom at Ujung Labung in the XVM century.

According to the story of Oemar Ngebe Suto Dilago in the Jambi State Act and Charter which was written in 1937 and then recorded, by H. M. M. Mennez, from the Colonial Institute, it was stated that Tun Talanai was a Marine Admiral, a former Mataram colony, from East Sarawak and Berunai, a Hindu. Tun Talanai became King of Jambi after Dewa Sekerabah (Pahit Lidah) died who was a Hindu. After Tun Talanai died, the power of the King of Jambi was handed over to Princess Selaras Pinang Masak, who came from Pagaruyung, the descendants of Adityawarman, adherents of Hinduism and Buddhism. It is understandable the actions taken by Ahmad Salim or Ahmad Barus II or Ahmad llyas in spreading Islam at that time because they were in pre-Islamic times. Since the arrival of Hinduism and Buddhism brought by priests and monks from India Thamil in 200 years BC, then during their development period they experienced a very long period of time, which lasted from the II century BC until the middle of the government of Putri Selaras Pinang Masak. According to Erch Fromm (1996) concluded that there is no culture that is not rooted in religion, where the relationship between religion and culture (inner) will give birth to civilization (birth) is stated.

Since the events of the struggle of Ahmad Salim or Ahmad Barus II or Ahmad Ilyas to destroy idols, he was held with Datuk Paduko Berhalo. Berhalo Island can be said to be the place where the Islamic Malay Kingdom was founded in Jambi. The next action taken by Datuk Paduko Berhalo in the Lambi Malay Kingdom was to introduce Islamic teachings within the Jambi Malay Kingdom court and pioneering the style of Islamic government in the Janbi Malay Country. Then Datuk Paduko Berhalo married Princess Selaras Pinang Masak who was blessed with four sons, namely Orang Kayo Pingai, the eldest son, Orang Kayo Hitam, Orang Kayo Kedataran and the youngest daughter Orang Kayo Fat. 
After the end of the reign of Princess Selaras Pinang Masak in the Jambi Malay Kingdom in 1480 AD, the reign was continued by her eldest son, Orang Kayo Pingai, who ruled from 1480 to 1500 AD. The spread of Islamic teachings was growing in the Jambi Malay State when the Jambi Malay Kingdom was ruled by the Orang Kayo Hitam in 1500 - 1515 AD or the XVI century AD. The Orang Kayo Hitam created an Islamic government and Islamized the Malay community as written by Umar Ngebe Sutodilogo Orang Kayo It was Black who Islamized Jambi. The first person who was converted to Islam by the Orang Kayo Hitam was his cousin who came from Pagaruyung who was later crowned as Sunan Muaro Pijoan, Sunan Kembang Sri, Sunan Pulau Johor which was symbolized by the replacement of the yellow turban for the white turban to be given the task of spreading Islamic teachings so that able to Islamize the Jambi Malay People at that time. According to the ruling official of the Jambi Malay Kingdom, one person. Priyayi, from Rajosari Suto Dilago, said that it was the Kayo Hitam who converted the Jambi people to Islam and this was reinforced by Tome Peres' notes, when he visited Sumatra Island in the early sixteenth century AD. He stated that the development of Islam in Jambi Malay Country was during the Malay Kingdom. Jambi was held by the Orang Kayo Hitam even though the Jambi Malay Kingdom did not show Islamic nuances at that time.

Orang Kayo Hitam who eliminated the delivery of the Pekasan Pacat and Kalong Tribute as a previously imposed agricultural product tax. According to Junaidi.T.Noor. Since the reign of the Orang Kayo Hitam came to power in the Jambi Malay Kingdom, Islamic teachings began to take root in the Jambi Malay Culture which is the Jambi Malay Traditional Identity as known as "Adat with Syara, Syara' with Kitabullah" which adheres to the Qur'an and Hadith. In the Jambi Malay tradition, it is called "Syara' mengato Adat Wear", the existence of the port of Zabaq is predicted, as a medium of contact and acculturation. Culture and religion undergo a process of creative interaction driven by geographical influences from the journey of the bearers of the teachings themselves (Symbiocics Relationship) and the existence of The State of Jambi is in the unity of the Malay Community (Culture Conception). This condition was marked by the arrival of foreign nations to the Jambi Malay country, such as I-Tsing, a young priest from China, and a teacher Atisa from India, who originally intended to deepen the teachings of Hindu and Buddhist 
Religion and Culture at Muaro Jambi Temple, developing a Hindu and Buddhist civilization that took place. in the VII to XIII centuries AD. Then the arrival of Muslim traders Arabs and Chinese Muslims who spread the teachings of Islam also developed Muslim civilization which took place in the XV to XVII centuries AD. That peaceful symbiosis happened on Jambi Earth.

After the end of the reign of Orang Kayo Hitam in 1515 AD, before being continued by the son of Orang Kayo Hitam, Prince Disappeared Diaek whose mother was Princess Mayang Mengurai who was the daughter of Tumenggung Merah Mato. The Kayo Hitam people have laid down the framework of Muslim culture and civilization even though the influence of Hinduism and Buddhism is still attached to the Jambi Malay people at that time. Islamic teachings have enriched the repertoire of traditional and cultural cultures so as to make the identity of the Jambi Malay Country.

The existence of the Lost Prince Diaek who is believed to be holding the kingdom with the title Penembahan Rantau Kapas ruled in 1515-1560 AD, the Lost Prince Diack has succeeded in pioneering the Islamic Government, so the first Sultanate in Jambi Malay Country was established in the XVII century AD which was held by Sultan Abdul Kahar from 1615-1643 AD which involved the role of the Jambi Ulama and the kings from Majapahit. At the end of the collapse of the Majapahit Kingdom there was a change in the title for the Jambi kings from "Penembahan" to "Sunan" which later became "Sultan" in running the government of the Jambi Malay Sultanate.

The title of Sultan was still attached until the time of Sultan Thaha Saifuddin who held the reins of the kingdom in 1855-1904. The shadow sultan was also the sultan who was appointed by the Dutch Colonial as a substitute for Sultan Thaha using the title of sultan. After the death of Sultan Thaha Saifuddin, the Jambi Sultanate was abolished and successively the sultanate changed to onder afdeling from Aideling Palembang and then became the Jambi Residency in 1906. Since 1957 the Jambi Residency was designated as Jambi Province..

Based on the author's field research, this tolerance occurred in Jambi Province, more precisely in Cempaka Putih Village, Jelutung District, Jambi City. Geographically, Jambi Province is located at $0^{\circ} 45^{\prime}-2^{\circ} 45^{\prime}$ South Latitude and $101^{\circ} 10^{\prime}$ $104^{\circ} 55^{\prime}$ East Longitude in the central part of Sumatra Island, to the north it is 
bordered by Riau Province, to the east by the South China Sea, to the Riau Islands Province, In the south it is bordered by the province of South Sumatra and in the west it is bordered by the province of West Sumatra. Jambi Province consists of 9 regencies, 2 cities, 141 sub-districts, and 1,562 wards/cities. With an area of 50,160.05 square kilometers. Jambi Province has many ethnic groups including the Kerinci tribe, the Kubu tribe, the Batin tribe, the Malay tribe, and several other minority tribes scattered in various regions.

Islam as a belief system/belief through the thoughts of the scholars in the corridor of Islam, and the belief system produces hablumminallah and hamblum minannas actions. Meanwhile, according to M. Abdul Karim said that what is meant by Islamic civilization are parts of Islamic culture which include various aspects such as morals, arts, and science, and also includes culture that has a technological system, building arts, fine arts, state systems. , and broad knowledge. 19

The presence of Islam began to spread to all levels of rural society in Jambi. In the spread of Islam, the island of idols is seen as a very important island in the history of Islam in Jambi. Because history records that it was from the island of idols that Islam was spread to all corners of the Jambi area. The presence of Islam brought fundamental changes to the social life of the Jambi Malay community. The religion adopted by the Jambi community before the entry of Islam was worshiping the spirits of the dead. Apart from the worship of spirits, there is another thing called belief in the power of supernatural powers, which can affect human life. These two beliefs are called animism and dynamism.

Islam slowly but surely, began to shift the Malay-Buddhist culture to the development of the Malay-Islamic culture. Regional culture is nothing but culture that grows and develops in the midst of local communities as supporters. Meanwhile, what is meant by Jambi Malay culture is a culture that grows and develops in the midst of the Jambi Malay ethnicity.

For the Jambi Malay community, their custom is Islam. Islam and adat are two inseparable things. A seloko that is often repeated is "adat based on syara', syara' with scriptures of Allah, syara' against custom of wearing". Seloko means that the customs or habits of the Jambi Malay community are based on the Shari'a derived

19 Rahyu Zami, (2018), Orang Melayu Pasti Islam: Analisis Perkembangan Peradaban Melayu, Jurnal Islamika Vol. 2 No. 1, p. 72-74. 
from the holy book; what is dictated by the Shari'a, will be used by adat. The strength of Islam held by the Jambi Malay community has implications, including the Jambi community's rejection of things that they consider not Islamic. The people of Jambi, for example, cut their history and took the arrival of Islam as a starting point. Islamization anywhere has never been very smooth. If not waves, small ripples color the process. In Jambi Malay society, the story about the ripple is never raised because it is part of a non-Islamic past, which they want to eliminate. ${ }^{20}$

Cempaka Putih Village is a residential area with various religions, ethnicities and cultures, including Islam, Christianity, Buddhism and Confucianism, while the existing ethnic groups or cultures are Malay, Minang, Javanese, Sundanese, Bugis, Banjar, Flores, Chinese and Arabic. The number of religions, ethnicities and cultures that exist in Jambi Province is caused in the 7th century AD a lot of traders from various regions and even foreign countries who came to take opportunities for cooperation in the field of trade between foreign countries and Jambi. This is said because Jambi's relations with foreign countries are more dominant in trade relations then diplomacy. These traders entered Jambi Province through the existing river, namely the Batang Hari river. This river is the transportation route for foreign traders to enter Jambi Province.

The community in Cempaka Putih Village communicates well and effectively despite having a heterogeneous culture, what causes this to happen is a sense of mutual need for each other, the importance of merging into one, and upholding the value of Bhinneka Tunggal Ika, this is what proves the application of da'wah. with the Bil-Lisan and Bil-Hal . methods.

The communication relationship that is applied is interpersonal communication. In interpersonal communication, communicators make predictions about each other on the basis of psychological data. Each tries to understand how the other acts as an individual, unlike in cultural and sociological relations. The range of permissible communication behavior is very different compared to the

20 Iqbal Shiddiki, Islam dan Peradaban Melayu Jambi, accessed through: Http://jambidaily.com/detail/iqbal-shiddiki-islam-dan-peradaban-melayu-jambi/2 25 April 2020. 
range of permissible communication behavior in non-interpersonal situations. Personal choices can be freely exercised in relationship development. ${ }^{21}$

The application of da'wah with the Bil-Lisan method is felt by the spaciousness of the heart to be tolerant, understand each other, and also pray for the best for a harmonious and prosperous life together. Like when the writer met one of the residents on behalf of Mrs. Surniati (her Chinese name, Asui) RT.09, 72 years old, 50 years old in Cempaka Putih, she said:

I was born in Bajubang, my religion is Confucianism and my culture is Chinese. Even though we have different religions and cultures, we get along here, mingle, and help each other especially when there is an event, I also help cook. I have 7 children, 3 Muslims, 1 Christian, and 2 Buddhists, but we in the family have never had problems, live life according to our respective religions and beliefs, and we also use the Jambi Regional language both with family and friends. neighbor.

The application of da'wah with the Bil-Hal method, the attitude of intercultural tolerance in Cempaka Putih Village is very closely related to the communication process, with community communication it can strengthen the spirit of humanity and unity. Likewise, when non-Muslims celebrate their holidays, they invite their Muslim neighbors to visit their homes, with the aim of gathering and eating together, and the food is halal specifically for Muslims.

Even in times of mourning, people still respect each other, for example, when they receive news that a non-Muslim neighbor has died, Muslims visit the funeral home and take them to the house of worship.

Likewise in a sports atmosphere, the ladies and gentlemen in the Cempaka Putih Village are very well known in Jambi City regarding the skill of playing volleyball, this of course happens because of good, solid, and effective communication between them, who basically have religion, ethnicity. and different cultures. What kind of communication process is used by adherents of different religions and cultures, causing this good communication to work.

21 Muhammad Budyatna and Leila Mona Ganiem, Teori Komunikasi Antarpribadi (Jakarta: Kencana, 2011), p. 10. 
QAULAN, Vol. 2, No.2, Desember 2021

Bela Ardila, Da'wah Amidst....

\section{CONCLUSION}

Diversity is a means for the progress of civilization. If we are only born from one tribe, never know other people's culture, never get along with various kinds of nation's children, and only know people around us, then our attitudes and behavior are like frogs in a shell..

Cultural differences are not meant to terrorize, coerce or kill each other. AlQuran introduces an extraordinary concept, namely diversity to get to know each other. By knowing the differences we can learn to build civilization. By knowing each other the differences between human beings, then we will be more tolerant. Misunderstandings often occur because we don't know each other's diversity.

The closeness of the people of Cempaka Putih Village is a reminder for us how important it is to live in harmony in the midst of differences. Caring, tolerance, mutual respect between religious communities can create a harmonious, harmonious and tolerant neighborly life.

\section{REFERENCES}

Al-Quran, Tim Penterjemah dan Penafsir, Al-Qur'an dan Terjemahannya, Semarang: Departemen Agama RI, 1998.

Agus, Hasan Basri, Pejuang Ulama dan Ulama Pejuang Negeri Melayu Jambi, Jambi: Pusat Kajian Pengembangan Sejarah dan Budaya Jambi, 2012.

As-Suyuthi, Imam, Asbabun Nuzul: Sebab-sebab Turunnya Ayat al-Qur'an, Jakarta: Qisthi Press, 2017.

Budyatna, Muhammad dan Leila Mona Ganiem, Teori Komunikasi Antarpribadi, Jakarta: Kencana, 2011.

Efendy, Onong Uchjana, Ilmu Komunikasi Teori dan Praktek, Bandung:PT Remaja Rosdakarya, 2009.

Hasbiyallah, Muhammad, "Paradigma Tafsir Kontekstual: Upaya Membumikan NilaiNilai Al-Qur'an”, Al-Dzikra Jurnal Studi Ilmu al-Qur’an dan al-Hadits, Volume 12, No. 1, Juni Tahun 2018.

Liliweri, Alo, Dasar-dasar Komunikasi Antarbudaya, Yogyakarta: Pustaka Pelajar, 2013.

Liliweri, Alo, Gatra-gatra Komunikasi Antar Budaya, Yogyakarta: Pustaka Pelajar, 2001.

M. Solahudin, "Pendekatan Tekstual Dan Kontekstual Dalam Penafsiran Alquran”, AlBayan: Jurnal Studi Al-Qur"an dan Tafsir 1, 2, Desember 2016.

Marwantika, Asna. 2019. "Potret Dan Segmentasi Mad'u Dalam Perkembangan Media Di Indonesia". Al-Adabiya: Jurnal Kebudayaan Dan Keagamaan 14 (01), 1-14. https://doi.org/10.37680/adabiya.v14i01.100. 
QAULAN, Vol. 2, No.2, Desember 2021

Bela Ardila, Da'wah Amidst....

Mulyana, Deddy, Ilmu Komunikasi Suatu Pengantar, Bandung: PT Remaja Rosdakarya, 2007.

Mulyana, Deddy dan Jalaluddin Rakhmat, Komunikasi Antarbudaya Panduan Berkomunikasi Dengan Orang-orang Berbeda Budaya, Bandung: PT Remaja Rosdakarya, 2010.

Najwan, Johni, Konflik Antarbudaya dan Antar Etnis di Indonesia serta Alternatif Penyelesaiannya, Jambi: Jurnal Hukum Edisi Khusus, 2009.

Oktaviana, Wahyu, Skripsi "Dakwah bil-hal sebagai metode dakwah pada masyarakat srikaton seputih Surabaya Kabupaten Lampung Tengah", 2020.

Pendidikan dan Kebudayaan, Departemen, Kamus Besar Bahasa Indonesia, Jakarta:Balai Pustaka, 2005.

Putra, Beni Agusti, Islam Dalam Sejarah dan Kebudayaan Melayu. Jurnal humanika Vol. 1, No. 2, 2016.

Putra, Heri Rahmatsyah, "Teori Komunikasi Antarbudaya", diakses melalui alamat http://herikomi.logspot.co.id/2016/08/teoi-komunikasi-antarbudaya.html, tanggal 17 November 2020.

Samovar, Larry A. et. Al., Komunikasi Lintas Budaya Communication Between Cultures, Jakarta: Salemba Humanika, 2010.

Shiddiki, Iqbal, Islam dan Peradaban Melayu Jambi, di akses melalui alamat: Http://jambidaily.com/detail/iqbal-shiddiki-islam-dan-peradaban-melayujambi/, pada 25 April 2020.

Wikipedia, "Al- Qur'an", diakses melalui alamat : https://id.m.wikipedia.org/wiki/Al-Quran, tanggal 6 November 2020.

Zami, Rahyu, (2018), Orang Melayu Pasti Islam: Analisis Perkembangan Peradaban Melayu, Jurnal Islamika Vol. 2 No. 1. 